Journal of Development and Communication Studies, Vol. 8. No. 1, January -June, 2021 ISSN (Online \& Print): 2305-7432. http://www.devcomsjournalmw.org

\title{
Media and Governance: Promoting Local Governance through Community Radio in Northern Ghana
}

Lawrence Naaikuur, Department of African and General Studies, Simon Diedong Dombo University of Business and Integrated Development Studies, Wa, Upper West Region, Ghana. Email:naaikuur@gmail.com E Africanus Lewil Diedong, Department of African and General Studies, Simon Diedong Dombo University of Business and Integrated Development Studies, Wa, Upper West Region, Ghana. Email: langyin45@gmail.com

\begin{abstract}
The study provides insights on how Royals FM and Radio Progress have, through innovative and strategic programming, become community mobilisers for tackling issues of communication and accountability in their local assemblies. The study employed a qualitative research approach. Interviews and focus group discussion were used to collect data from two purposively selected Community Radio Stations $(\mathrm{CR})$, and from some community members and other stakeholders in local governance. A key finding of the study was information access difficulties to assist CR conduct investigations on suspected cases of corruption. Another was the public's partisanship perceptions of CR watchdog functions in exposing corruption, which disincentivised both stations from investigating corruption related issues at the District Assemblies (DA). The study concludes that the little evidence of corruption revelations at the assemblies by the stations despite reports of corruption being a bane to local development efforts, suggests that CR need to overcome all obstacles to enable them effectively perform their community broadcasting mandate as expected. The study recommends a speedy operationalisation of the Right to Information Law of the country. There is the need for the Ghana Community Radio Network to organize periodic training programmes for its members and owners of $C R$ to enable them to strictly adhere to their non-partisan ethos so as to enable them gain public trust in their role as non-partisan arbiters in Ghana's local governance.
\end{abstract}

Keywords: Community Radio, Local Governance, Decentralisation, Governance Accountability, Information Access 


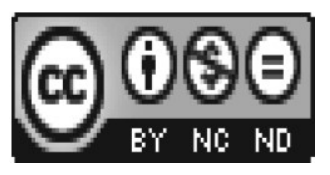

(C) 2020. The authors. This work is licensed under the Creative Commons Attribution 4.0 International License (CC-By-NC-ND). Users may freely share and redistribute this work provided that the author and the Journal of Development and Communication Studies are fully acknowledged. Users may not tweak or remix and offer this work for sale. The full license may be accessed at https://creativecommons.org/licenses/by-nc-nd/4.0/

To cite this article: Lawrence Naaikuur, \& Diedong, A.L. A.C. (2021). Media and Governance: Promoting Local Governance through Community Radio in Northern Ghana (2021). Journal of Development and Communication Studies, 8(1), $144-163$ https://dx.doi.org/10.4314/jdcs.v8i1.7

\section{Introduction}

Communication can serve as a means of promoting good governance practices within the decentralised system of governance in Ghana. A key motivation behind developing countries-wide decentralisation embarked upon in 1990s has been to enhance communication as a means to promoting good governance at the local level (Mansuri \& Rao, 2012). Decentralists believe that bringing governance closer to local people will promote proximity between them and governance authorities to enhance communication flow. Local people can have better access to information on the activities and conduct of local government officials with which they can monitor the activities of the duty-bearers and to hold them to account.

The importance of communication in all levels of governance for human development has been underscored in scholarship (see Haider et. al., 2011). Communication serves as the main matrix for the government-citizen engagements on governance and development, acting as a catalyst in facilitating information flow between people and decision-makers, in promoting dialogue, and facilitating horizontal debates among active citizens. Effective communication between citizens and local authorities is crucial in enhancing the ability of civic groups to influence the delivery of services to local citizens as well as the management of the most pressing questions of local development (Servaes, 2009).

Ironically, a major weakness of developing countries local governance relates to communication. There seems to have been an embedded communication problem in the decentralised governance systems of many of the countries. In his reviews of major works on multi-country studies of decentralisation across Sub-Saharan Africa, White (2008) finds that although most African countries are making efforts to decentralise government decision-making so that government will be more accountable, this usually has not improved accountability because of a disconnect in communication between district or ward councils and local communities. It is 
observed that weakness and insufficient platforms or systems for citizens-local authorities' engagement on development issues and for promoting and facilitating dialogue that, on the one hand, could strengthen the articulation of community voices, and on the other hand, enhance transparency and accountability of government policies and initiatives.

Studies (Servaes, 2009 \& Norris, 2010) note that a robust and independent media sector can take up a central and unique role in providing citizens with the information they need to participate effectively in consultative processes and are crucial in stimulating social demands by local actors as well as empowering people to demand for better services from the local authorities and public institutions. However, scholars such as Hyden et al. (2002) and Nyamnjoh (2005) have reported on a developing country-wide weakness in the role of the media in promoting effective decentralisation. Media's involvement in local governance can be contextualised within a broader context of factors that influence the media's governance functions. Media control by the economically and politically powerful has been a subject-matter of intellectual discourse (Karikari, 2020). Despite the existence of legal and constitutional guarantees of media independence, public media that are supposed to be independent of government in order to serve the public interests are often susceptible to governmental controls. Private commercial media particularly broadcasting seem to lean towards pursuing economic and political interests. In this light, the ability of the two categories of media to pursue public interests including the promoting of local governance has often been compromised.

The study explores the role of $\mathrm{CR}$ in tackling pertinent issues about accountability of local authorities to communities. Specifically, it examines how local governance-related programmes on Royals FM in the Bono East Region and Radio Progress in the Upper West Region are implemented.

\section{Local governance in Ghana and community radio relevance}

Ghana's decentralisation provides a viable institutional framework for the promotion of good local governance for accelerated development. Ghana's local governance is geared towards greater accountability by the local government units, the Metropolitan, Municipal and District Assemblies (MMDAs) to local communities. Accountability is provided for in the legislative instrument that created the MMDAs. Of particular importance for this study is Article 16(1) (a), which stipulates that members of elected community representatives to the MMDAs to report to their people on the work of the DA. "A member of the MMDA shall ... maintain close contact with his electoral area, consults his people on issues to be discussed in the DA and collate their views, opinions and proposals." The assembly member is further expected to present the views of the people to the DA; attend sub-committee meetings of the DA; and meet the electorate before any scheduled meeting of the DA. The 
requirement for the assembly member to organise regular meetings, hold consultation with the electorate and collate joint opinions.

Despite these elaborate constitutional provisions, the reality on the ground points to widespread dissatisfaction with the state of accountability in Ghana's local governance. In Akudugu et al. (2012) study of a decentralised system as a framework for promoting participatory and bottom-up democracy and the citizenry-local officials' accountability relations in Bawku District of the Upper East Region, most of the respondents complained their local Assembly was not accountable to the people on development projects.

Concerns about lack of accountability are also highlighted in multi-district study by Sustainable Enterprise Development of Ghana (SEND-Ghana, 2014). The study shows citizens' dissatisfaction about the use of the District Assembly Common Fund (DACF) in 48 MMDAs in the Northern, Upper East, Upper West and Greater Accra Regions. According to the study findings, about $80 \%$ of the respondents showed poor knowledge of approved projects, budget information, among other barriers. The study blames the weaknesses of accountability in Ghana's local governance on poor flow of communication and lack of a genuine voice for the least voiced.

The argument of the study is that the Assembly Members' role of maintaining close contact with their electorates is essentially a communicative one, that is, their ability to facilitate internal community communication and to link the electorate to the MMDAs. Gaps in effective communication seems to be a drawback on how rural communities and $\mathrm{CR}$ can demand accountability from duty-bearers to ensure that resources meant for development are well utilised.

Despite enormous potentials of the Ghanaian media to champion a local governance improvement agenda (MFWA, 2015), the findings, however, showed that reportage, advocacy and programming on local governance issues on radio were very low both in quantity and quality. The majority of studied radio stations did not have specific programmes that focused on local governance issues and when they did, such programmes were allocated less time compared to other programmes. These findings point to the need to examine whether $\mathrm{CR}$ contribution can make a difference in local governance in Ghana

\section{Methodology}

The study adopted a qualitative research approach. Royals FM was purposively selected for the study based on its outstanding engagement with local governance and development issues (see Diedong \& Naaikuur, 2012 and GCRN, 2014). The selection of Radio Progress for the study was motivated and informed by our (researchers') monitoring of the station's programmes in which local governance is a daily feature. In terms of the geographic scope of the study, the researchers categorised members of 
GCRN into two zones: southern and northern zones. Royals FM and Radio Progress were purposively sampled among community radio in the northern zone because of their consistent attempts at integrating local governance in their programmes.

Data were collected through in-depth interviews and focus group discussions involving stakeholders in Ghana's local governance and community radio stations. In the study on Royals FM, in addition to local level interviews, an official from the Ministry of Local Government and Rural Development (MLGRD), the agency responsible for local governance in the country and one from the GCRN were interviewed. The aim was to gain their perspectives on the role of CR in Ghana's local governance. At both Royals FM and Radio Progress, interviews were conducted at three levels. One was at the CR stations level involving the stations' Managers, a member of the governing councils of the CRs, and three lead producers of local governance programmes. Another local level category of respondents consisted of two assembly members from each of the stations listening communities, and an official from the DA. Of particular importance, at each location, a chief who was identified in the community as a keen listener of the selected stations and knowledgeable on local governance issues became a key informant interviewee in a bid to incorporate the perspectives of the traditional rulers.

The focus group discussions involved community members at each study site. There were three groups: one located close to station and two others in more remote villages participated in the discussions. They consisted of three males and three females selected based on their known political activism relative to local governance and for being regular listeners to their community stations or as participants in the station's local governance programmes. Data analyses used Norris's (2010) conceptualisations of the media-governance functions as watchdog.

\section{Conceptual Context}

From the 1990s, many developing countries began to move away from centralised governance of colonial and post-colonial periods to embrace decentralisation as an important aspect of good governance. Virtually all sources agree that decentralisation basically aims to create local governance by transferring authority, resources and accountability from central governments to local government systems (see Mansuri \& Rao, 2012). Shah (2006:3) sees local governance as a

... framework for citizen-citizen and citizen-state interactions, collective decision making, and delivery of local public services...it includes the diverse objectives of vibrant, living, working, and environmentally preserved self-governing communities.

Thus in effective local government systems ordinary people assume central roles of participating in policy decisions, demanding accountable governance, which would improve their lives. These rights are legally guaranteed. Indeed, within a local 
governance system, power and authority are exercised among different stakeholders and actors in taking important decisions. It seeks to include the multiplicity of formal and informal relationships between different actors in development that include civil society organisations and the media that shape and influence the output and effectiveness of political and administrative systems at a subnational level (Oluwu \& Wunsch, 2004)

Good local governance is best defined by clarifying the term, good governance. According to Elahi (2007:5) qualitative governance is characterised by the application of processes and mechanisms that are:

participatory, transparent ... accountable ... effective and equitable ... promotes the rule of law ... ensures that political, social and economic priorities are based on broad consensus in society and that the voices of the poorest and the most vulnerable are heard in decision-making over the allocation of development resources.

Good governance may be understood by unpacking its key principles from the above definition. Thus a governance system can be described as "good" when, among others, there is effective citizen involvement (participation) in decision-making processes about how economic and social resources are allocated, delivered, used, and maintained; when there exists transparency marked by free communication flow between citizens and government on a wide range of issues; when there is accountability in which public officials and institutions are ready to explain and justify their actions and decisions to the public; and when there is responsiveness, requiring that institutions and processes try to serve all stakeholders within a reasonable timeframe.

A simplest appreciation of good local governance can be obtained by the application of the good governance principles outlined above at the local level. Indeed, the Aberdeen Agenda on the Commonwealth principles on good practice for local democracy and good governance adopts these indicators in its 10 principles. In this study, the principle of accountability articulated within the Aberdeen's Agenda is worth highlighting. Accordingly, local governance has to be conducted in a manner that is accountable to the community it serves based on robust and independent regulatory bodies put in place to safeguard against corruption, mismanagement and the misappropriation of resources by local government.

It is imperative to clarify the principles of accountability in its general terms and its applicability in this study. Accountability demands that public officials inform citizens and are made answerable for their policies and actions that affect the citizens' wellbeing. These officials must be willing to be sanctioned accordingly. Accountability behooves power holders, particularly public officials, to answer for the manner in which they exercise the power entrusted them (World Bank, 2005). 
Furthermore, accountability holds that all power holders, including the state, should be prepared for reward for good performance, or for sanction for abuse. As an important aspect, elected representative are obliged to report regularly to the electorates on their work and are required to meet the expectations as well as fulfill promises.

The World Bank cited above and other institutions recognize corruption as a key concern in governance accountability. Generally defined as the "use of public office for private gain," corruption has in recent times attracted massive waves of concern and debates, centering on its effects on the construction of good governance and development. It is considered one of the worst forms of economic injustices as it goes to benefit individuals and sections of society to the detriment of the public good. Therefore, good governance calls for effective mechanisms to prevent, check or deal with corruption.

The World Bank identifies two categories of accountability: supply and demand side accountability. The supply side accountably also termed upward accountability is directed towards central government and as such, considered an ineffective tool in holding governments answerable to citizens (World Bank, 2005). A classic example is represented in Ghana's local government system where the MMDCEs owe near total allegiance to the sitting presidents and the ruling political parties that appoint them.

Demand-side accountability, as the second set of accountability mechanisms, includes what is termed social accountability. Social accountability has arisen as a response to the ineffectiveness of the supply side ones in promoting public accountability and have therefore, been upheld as being the most effective governance accountability mechanisms. Social accountability is an approach towards building accountability that relies on civic engagement, empowering ordinary citizens and CSOs to participate directly or indirectly in exacting accountability. It uses a broad range of actions and mechanisms beyond voting that citizens can use to hold the state to account. The approaches usually involve government, civil society, media and other social actors that promote or facilitate these efforts (McNeil \& Takawira, 2006; Wildermuth, 2014). Social accountability is applicable in this study because it involves community mobilisation by $\mathrm{CR}$ for local governance engagements and scrutiny.

\section{Local Governance Accountability}

Accountability is an important reason for decentralisation. Theories of decentralisation for better governance posit that local governance offers improved opportunities for direct citizens-engagements with governance structures, thereby empowering ordinary local citizens to demand answerability from their leaders on their actions or inactions (Grindle, 2007). Decentralised governance has, therefore, been touted as a major means to reducing local level corruption. Mansuri and Rao 
note that, local people "are more likely to notice when local government officials steal money from a construction project, engage in nepotism, or spend their budgets without taking the views of their citizens into account" (Mansuri \& Rao, 2013: 17)

However, it is worth noting that not all decentralisation programmes create good local governance. Decentralisation that leads to effective accountability emerges when there is "downward" accountability where authority and accountability are devolved and distributed to communities (Oluwu \& Wunsch, 2004). Greater accountability to communities is key in vesting citizens with greater powers to hold all levels of local government officials to account. Mexico, Argentina, the Philippines and South Africa are examples of such success stories (Grindle, 2007). Contrary situation, obtains in many developing countries that undertake decentralisation reforms that are not designed to lead to viable local governments. This situation, which is a common feature in many African countries including Ghana, is characterised by recentralisation whereby greater accountability of some or all local government officials is towards central government and central government. Oluwu and Wusch (2004) interpret this cosmetic approach to decentralisation to mean the political actors who announce the reforms do not actually want to shift power and resources away from them. White (2009) reports that the leaders and their dominant political parties decide to maintain tight control of the local government units to, among other purposes, reward political leaders with jobs and funding and to prevent significant political opposition White concludes that this strategy enables local leaders to continue their exclusive access to wealth of the nations

Contrary to the assertion that strategy reduces corruption, many experts argue that decentralisation in many contexts does increase the opportunities for corruption (Santi 2012; Masuri \& Rao, 2012). Fundamental factors assigned include the effects of the movement of allocative decisions further out of the limelight of central government; weak and ineffective institutions of participation and accountability; and rampant political interference in local affairs (Aroga 2011) For example, Masuri and Rao (2012) found exacerbated corruption particularly in many remote, poorer communities with social inequalities and where there are low education levels as well as low exposure to media and information.

Ghana's decentralisation programme is fraught with the accountability challenges. Despite elaborate constitutional provisions, the reality on the ground points to an attempt at recentralisation. Analysts of the country's local governance system have described it as one designed in a top-down approach to facilitate centrelevel control of key decisions (Ofei-Abogye, 2008). Arguably one of the greatest examples of the centre-level controls is central government appointments of the chief executives of the MMDAs known as Metropolitan, Municipal and District Chief Executives (MMDCEs). The Constitution empowers the President of Ghana to appoint them in consultation with other stakeholders in each district. Apparently, the 
main determinant of the appointments is loyalty of the appointees to the political parties in power, a situation that can be likened to a reward system for political party foot soldiers. This phenomenon is a serious clog to accountability because it makes the MMDCEs largely accountable to central government and almost non-accountable to the local people. Among other negative effects, the MMCEs see themselves as representatives of central governments and wield enormous dominance over the assemblies (Ayee, 2004). In effect, while local communities can elect representatives to the MMDAs, funding and effective permissions are given exclusively to the MMDCEs from the central government.

Another serious accountability challenge in Ghana's local governance is corruption at the MMDAs. Year in year out, the Auditor General of Ghana Annual Reports reveal widespread irregularities and procurement procedure breaches in the use of the central government financial allocations to the MMDAs for development, known as the District Assemblies Common Fund (DACF).

Two conditions have often been singled out by scholars as being crucial for improving local governance accountability. Apart from the role of the media, competitive elections of councilors have been underlined by Grindle (2007) and Masuri \& Rao (2012) for holding enhanced opportunities for greater accountability of local governance. Accordingly, local officials are likely to be more mindful of the activities they carry out, while voters are more likely to have better information on local government performance. This can enable voters in local government elections to reward or punish, respectively, those who perform well and those who do not.

\section{Media and Governance Accountability}

A well-known conception of the media's governance role is the one by Pippa Norris. Norris summed up the role of the media as civic fora, watchdog, and agenda-setter. The watchdog function that is more directly relevant to this study (see Norris, 2010). Media scholars such as Servaes (2009) and Ali (2005) are unanimous that the watchdog function of the media is rooted in the media accountability role in governance. The media act as watchdogs over society by keeping a 'critical eye' and giving an 'attentive ear' over decision-makers and the performance of public and private institutions. The aim is to highlight policy failures, maladministration, abuse of power, corruption and scandals in society. When the media perform their public watchdog role effectively, they serve as critical checks on government misuse of power or incompetence, and enables citizens to demand good governance.

Robust and vigilant media systems have been underlined as being powerful instruments against corruption. Servaes (2006) perhaps best captures the media corruption-fighting strategies by positing that the media can raise public awareness about corruption prevalence, raising it as an important governance issue and creating a space for discussion on the canker to form public consensus to fight it. Transparency 
and free flow of information lie at the heart of accountability. Investigative journalism is a cardinal watchdog function and many societies and states rely on the independence of the media to investigate and interrogate government policy in the public interest (Coronel, 2005). According Coronel (2005) investigative journalism can target low-level to high-level officials and the subjects can range from small wrongscale doings involving petty officials to high-level political corruption.

There is a wealth of individual cases that point to the role of the media in exposing corruption in different contexts across the developing world in recent times. Particular examples include the eventual resignation of Alberto Fujimori from the presidency of Peru following the revelations of wrong doing and corruption by the print and electronic media (UNDP, 2007). In South Eastern Asia, the press is reported to have been acting like attack dogs unleashed on erring officials and corrupt institutions following the fall of dictators (Coronel, 2006). In Ghana, examples of media corruption expose abound following the media freedom spurred by the 1992 constitution. Perhaps the most notable watchdog works in more recent times is by Anas Aremeyaw Anas of global fame for his undercover investigations. One of the investigative pieces involved the capturing of judges on camera receiving bribes to set under trial criminals free. This exposé led to the sacking of higher and lower court judges implicated in the scandal by the Ghana's Judicial Service.

There are an increasing number of case studies on CR and local governance in countries across the world. But an AMARC's report that captures experiences in 96 countries that showcase CRs empowerment of local communities for demanding accountability from local authorities sums them up : "Community Radio has made possible for ordinary people to have powers to summon their leaders and make them accountable for how they are using public resources" (AMARC, 2007:41).

\section{Findings}

The findings established that the non-partisanship principle of $\mathrm{CR}$ was the most prominent influencer of respondents' perceptions of CR stations local governance role within the politically polarised media environment in Ghana. Put in context, a key distinguishing feature of community broadcasting from other broadcasting systems is its non-partisan orientation. Most sources agree that the non-partisan ethos of CR means community stations operate devoid of political and ideological manipulations, contrary to the partisanship that often characterise public and commercial broadcasting (Alumuku, 2008). This finding is indicative of the need for community stations to maintain an independent editorial policy from governments and political parties' influences.

The data confirm that the non-partisan ethos of a CR is a key generator of public trust in its local governance agenda. The data also revealed how CR in Ghana take seriously the non-partisan principles. The GCRN has formulated Codes of 
Conduct to insulate member stations and their workers from falling prey to the deeply politically polarised media environment in Ghana. Members are sanctioned when the codes are violated. The "Non-partisanship Code" was enacted in 2014 to position the stations to pursue local governance agenda devoid of partisanship (GCRN Nonpartisanship Code, 2014). A key informant from the GCRN claimed that by their nonpartisan character, members stations earned public credibility for the watchdog functions by, for instance investigating corruption in their District Assemblies without fear or favour of any political party in power. Across the different interviews, the non-partisan orientation of CR as the centre-piece of the credibility of CR in its watchdog role over local governance was a recurrent theme was highlighted.

The study found several governance-related programmes on both Royals FM and Radio Progress. Some of the most innovative programming formats tailored towards promoting both communication between local government officials and communities as well as mobilizing the communities for exacting accountability are the following:

i) Yen Assembly Fuo Mire on Royals FM.

Yen Assembly Fuo Mire which means Meet your Assembly Members is a standing programme on Royals FM. Broadcast every mid-week, it is dedicated to assembly persons within the Wenchi Municipal area to account to their electorates on their stewardship. The programme demands from them to report on their responsibilities to their communities and their work at the assembly as their people's representatives. Each assembly person had the opportunity to feature on the programme at least three times during the year. The programme had such a compelling force that even Assembly persons who lived in distant places outside the district and region, endeavoured not to miss their turns on the programme. Assembly members who miss their turn on the programme without prior notification and on reasonable grounds do so at the peril of invoking indignation of their constituents.

The programme took the form of interviews between a host from Royals FM and the assembly persons followed by phone-ins from listeners. The assembly persons were asked questions on a wide range of issues such as the frequency of meetings with their electorates, happenings in their Electoral Areas and development problems and projects. Their electorates, and the general public who were usually pre-informed about the days of appearance of the various assembly persons on the programme, were encouraged to phone in to ask questions on the claims of their assembly persons. The programme was described by different respondents as hugely impactful. For instance, some of the local people claimed Yen Assembly Fuo Mire served as a very effective communication and engagement platform between them and their assembly members. On their part, some of the assembly members testified that the programme 
enabled them to reach their electorates, noting that since they were not in the position to regularly visit the people as constitutionally mandated for logistical reasons.

Meet your Assembly Members provided opportunities for the electorates to vent their anger on the assembly persons on numerous issues ranging from their failure to communicate with the communities as required of them to broken electoral promises on the provision of social amenities as well as the general problems of underdevelopment. Although the programme generally generated lively debates, they were also often tension-packed. During data collection, an on-air confrontation was witnessed between callers from a community called Akete and their assembly person over what the callers termed a calculated attempt by the assembly member to misinform the public about the state of the primary school in the area. When the assembly member feigned ignorance about rainstorm having ripped off the roof of the school, an angry resident insisted he had personally informed the assembly about the problem long ago. It took a skillful host to save the programme from being marred as other callers wanted to lambast the assembly member for being a liar. According to one of the assembly persons, the programme "often puts us face to face with our angry electorates who pour their venom on us for almost all the problems in the community."

Meet your Assembly Members extended to other officials of the Wenchi Municipal Assembly. Sector Heads of the DA were occasionally invited to the programme to account on happenings related to their sector. For instance, Municipal Environmental Sanitation officers and those from the Education and Health Directorates had to appear often times on the programme to answer questions on the states of environmental sanitation, educational and health facilities.

\section{ii) Bombe a yiri (What is in your Community?) on Radio Progress}

"Bombe a yiri" or "What is in your Community?" was a flagship accountability programme instituted by Radio Progress to present an open microphone to village communities to voice their needs and to hold duty-bearers to account. Broadcast daily during peak listening hours in late afternoons, it was packaged in a mixed bag of prerecorded community voices, studio interviews and community-wide participation through phone-ins. Field reporters were deployed to organiSed community durbars of chiefs and their people, which provide avenues for discussing a wide range of development issues. Topics typically coalesced around the lack of basic services such as potable water, bad roads, poor schools' infrastructure and lack of teachers and abusive health workers at community health facilities.

Each week was dedicated to one village community in the five administrative districts within the defined larger community of Radio Progress. These districts are the Wa Municipality, Wa East, Wa West and Nadowli-Kaleo. The meetings were 
usually characterised by frank and open discussions, which often generated debates. The sessions were facilitated by the reporters who were skillful in animating such community-level debates that bring in everyone to participate. The sessions are recorded and edited to be played on air. To allow for free discussions, the assembly members of the respective areas were deliberately left out of the meetings. Rather, assembly members and the District Chief Executives were pre-informed about the programmes and alerted to hold themselves in readiness to be called to respond to concerns raised by the people on air.

As an interesting strategy, selected parts of recorded electoral promises that had been made by assembly members during their campaigns were played during the programmes as basis for assessing their performances. For instance, if a certain community raised issues on education, promises made by the assembly member for the community to solve such problems would be played on air to match the villagers' concerns. To make possible this, Radio Progress had undertaken civic education on the assembly elections since 2000 that provided free airtime on equal basis to all assembly member aspirants for their campaigns. Each of the campaign broadcasts had been recorded. In addition, staff reporters were assigned to track their campaigning at the communities and record the messages there.

Following the airing of the community voices, the assembly members were invited to respond. Alongside, phone lines were open for public participation. To empower female participation on the programmes, separate phone lines were dedicated to them. Usually, the phone-ins reinforce the community voices. Assembly members who have acquitted themselves through their good performances were praised but those whose inefficiencies had been made evident were blamed. Focus group participants in communities of Charia in the Wa Municipality, Loho in the NadowliKaleo Districts and Dorimon in the Wa West District praised Radio Progress for bringing the microphone to ordinary, poor and marginalised people to express themselves.

\section{iii) Foo Ane a fo DCE (Citizens Meeting their DCE) on Radio Progress}

Foo ane a fo DCE or Citizens, (Meet your DCE) was another programme on Radio Progress. It was a weekly programme broadcast at the end of every month. DCEs were invited to respond to portions of recordings which focused on the poor states of essential services such as education, health, roads and sanitation that had been raised in the Bombea Yiri. The radio listeners were invited to phone in to demand that the problems be fixed.

Interviews with programme producers revealed mixed experiences in getting the DCEs on the programme. While some were described as eager and sought opportunities to appear to account on their stewardship, others were reluctant. The unwilling ones usually had to be persuaded or pressured by their communities to take 
their turns on the programmes. Notable among the willing ones was the MCE for Nadowli-Kaleo who is the only female DCE in the stations coverage area. She has often been praised by the general public for her sterling performance on air, backed by reports of her performance in tackling challenges of education, health, roads, amongst other services.

\section{Discussion}

The innovative programming by Royals FM and Radio Progress demonstrate their ability of to pursue good local governance agenda and to address some of the key accountability issues in Ghana's local governance. Notably, the two programmes, Royals FM's Yen Assembly Fuo Mire and that of Radio Progress's Bombe a Yiri effectively addressed the communication gaps between not only the assembly persons and their communities, but also between the local people and the district assembly as a whole. By providing avenues for regular contacts and engagements between assembly members and community members on the other, the programmes enabled assembly persons to fulfill their mandate of maintaining regular contacts with their constituents and account for their stewardship as the people's representatives.

It is interesting to note how the radio stations were refashioning journalism to involve the people in discourses on local governance, thereby empowering otherwise voiceless sectors of their societies to monitor the workings of their assemblies on a day-to-day basis. The constant interactions and participation by the people in discussions on the governance programmes can be said to be creating a sense of 'citizenship', a concept Moufte cited in Rodrigueez and Miralles (2014) explains as more about the participation of people in everyday political practices than something that is guaranteed by merely in being part of a system.

Another key accountability issue in Ghana's local governance relates to the very powerful positions of the appointed MMDCEs whose only accountability is almost entirely upward to their appointing authority - the President of Ghana. It is important to underscore Radio Progress's ability to successfully introduce a level of accountability for the MMDCs through the Citizens Meet their DCE's programme. A Legal Officer of the MLGRD (key informant interviewee) had expressed hopes that CR could be used in involving MMDCEs in local governance discourses for an effective accountability in the system because of its non-partisan character. Radio Progress programme, therefore, brings that hope to a level reality.

However, contrary to Radio Progress's case, the study found no similar programmes on Royals FM. Indeed, a major gap in the accountability role of Royals FM was the station's apparent inability to hold the MDCEs of the Wenchi Municipal to account. The station's Head of Programmes described it as always being a daunting task to convince most of the MCEs on the value of using the station to facilitate their regular interaction with the people. He recalled a few occasions when some MCEs 
had to be put on the spot through on-air calls to respond to certain allegations of wrong-doings at the Assembly. Most of the MCEs had, at best, shown little enthusiasm in availing themselves regularly on air or at worst, shown absolute disdain in that regard with the excuse that they had to seek "clearance from above" to speak on certain issues since they were directly answerable to the President Ghana. Though more studies are needed on the attitude of the MMDCEs towards CR as a reliable means of communicating on Ghana's local governance, Radio Progress's relative success story is refreshing. It sheds a glimmer of hope on the prospects of popularising the use of $\mathrm{CR}$ as medium that favours dialogue between the leadership of Ghana's local governance system and community members. It suggests that Royals FM and other stations can sensitise and mobilise the community to make direct demands in irresistible ways that the MCEs should communicate to them through their community radio stations.

Corruption is a bane to achieving accountable governance at the local level in Ghana. As has been upheld throughout this study, the media is a powerful mechanism for fighting governance corruption through its watchdog function. However, the findings did not present an encouraging picture on the ability of the two stations to investigate and bring up corruption cases in the districts. The only evidence of such exposure was found at Royals FM involving inflation of contract sums for projects by officials at the Wenchi Municipal Assembly. The case was investigated based on a tip from a whistleblower. However, further evidence on the sustainability of such efforts was lacking, making it look as if that exposure was the first and last of its kind.

At Radio Progress, there was no evidence on corruption revelations at any point. However, the data pointed to high public expectations of regular corruption revelations by $\mathrm{CR}$ stations as a crucial means to tackling the canker of corruption in Ghana's local governance. In the words of a Legal Officer (an Interviewee from the MLGRD): "If a DCE steals money, a CR should report that the DCE has stolen money. Period! The DCEs are not above the laws of the country". An interviewee (a prominent chief) added: "Corruption at the DA is a major reason for the lack of development in rural parts of Ghana. What would make us more joyful is to hear on Radio Progress every day that it has found bad things at the Assembly?"

Two main factors were pointed out as constraints to the ability of the stations to expose corruption at their local Assemblies. These were information access difficulties and perceived partisan motives associated with the stations' accountability programmes by the public. During interviews with programme producers at both stations, they bemoaned challenges they encountered in obtaining official information from the Assemblies even on harmless matters like their Development Plans and Budgets. As such another important missing link in their accountability endeavours was a lack of focus on monitoring the effective implementation of the two key policies 
and the judicious use of the District Assemblies Common Fund meant for development. The state of affairs is not peculiar to CR. Journalism practicec in Ghana is fraught with information access difficulties, a situation which constitutes a serious setback to the media's governance agenda. The phenomenon of journalists' difficulty to access information from offices seems widespread. A panelist at a GTV discussion programme: "Media and Democracy" expressed concern about the monetisation of access to information (GTV Programme, 2020). Over the past decades the problem has worsened due to absence of a functional right to informational law (RTIL). Ghana passed an RTIL bill into law in March, 2019. But up till now, it is unclear when the law will become fully operational.

On the issue of partisanship perceptions, this study and earlier ones (see GCRN, 2014) showed that despite claims of strict adherence to the political neutrality by the GCRN stations, there were deep-seated public perceptions that CR in Ghana were not truly non-partisan in their operations. At the community-level interviews at both stations, controversies surrounding the stations adherence to the non-partisan ethos signaled divided opinions. Whilst Management and workers of the stations touted strict adherence, some respondents thought otherwise - making allegations that the stations were often times demonstrating biases in favour of one or other of the two dominant political parties in the country, namely the National Democratic Country (NDC) and the New Patriotic Party (the NPP). At Royals FM, which is located in an NPP stronghold, some respondents including a traditional ruler (a key informant) held the view that the station and its workers were leaning towards the NPP and had often sought to build up the Party's fortunes and downsizes those of the NDC particularly during election periods. Similar observations were made about Radio Progress. Some respondents in the Wa Municipality even named some of the key producers as those demonstrating partisan tendencies in their work. A respondent, who claimed to have been a serial caller on the station's accountability programmes, narrated how she had been a victim of discrimination. She alleged that one of the hosts often truncated her calls without assigning any reasons. Evidence gathered on monitoring phone-in calls on the accountability programmes, showed how the callers were divided between NDC and NPP on discourses on development issues with seeming encouragement of the phenomenon by the hosts.

Programme producers at both stations said they had been victims of political witch-hunting for their work on accountability programmes. They intimated that the state of affairs was beginning to have chilling effects on them, though they were determined to carry on. It is important to note that it was the seriousness of the partisanship perceptions of $C R$ stations dabbling in partisanship that prompted the GCRN'S 2014 studies that led to the enactment of the Non-partisanship Code of Conduct. 
The struggle by CR to maintain its non-partisan ethos is a global phenomenon. Studies by AMARC, 2007 \& Jallov, 2012 affirms that one of the greatest struggles of $\mathrm{CR}$ all over the world has been how to maintain its independence from political interests. Ironically, the more CR stations try to maintain their distance from political influences, the more attractive they become to the politicians who also see it as a more reliable means for them to reach grassroots marginalised people than other media types with their messages.

\section{Conclusion}

The study demonstrates that CR can be a unique medium for promoting good local governance in Ghana. The study provides insights on how Royals FM and Radio Progress had through innovative and strategic programming, become community mobilisers for bridging communication gaps between duty-bearers and citizens by empowering low-status people to demand accountability.

However, significant challenges that constrained better ability of the stations to effectively act as watchdogs over local governance need to be reiterated. The fact that little evidence of corruption revelations by the stations at the DA was established despite reports of corruption being a bane to local development deserves special attention. Part of the problem can be attributed to information access difficulties from the Assemblies to facilitate corruption investigation. The study recommends the speedy implementation of the RTI Law. Community stations attempts at subtly dabbling in political partisanship despite the GCRN's non-partisan codes is a cause of concern since this violates core principles underpinning the operation of CR. The study recommends GCRN and Media Development Partners to organise periodic sensitisation workshop on the issue for owners and staff of $\mathrm{CR}$ radio stations to enable them desist from the practice.

\section{References}

Akudugu, M.A., Fielmua, N., \& Akugri, W.K. (2012). Effectiveness of grassroots participation in local governance in Ghana's Upper East Region: The case of assemblies in the Bawku Area. Journal of Local Government Studies, 4 (1), 78-104.

Ali, S.I. (2006). Governance and the Media (CGS Working Paper). Retrieved from https://pdfs.semanticscholar.org/ba5d/a587e25a9446ceb9962022c099f4f5907f2a. pdf?_ga=2.20424191.658624348.1581007728-688646569.1574113655.

Alumuku, P. (2007). Community radio for development: The world and Africa. Nairobi: St. Paul Publications.

AMARC (2007). Community radio impact assessment - Removing barriers, increasing effectiveness: Challenges, findings, lines of action for community radio stakeholders"(AMARC Global Report). Retrieved from 
http://www.amarc.org/documents/books/AMARC_Evaluation_book_June_207. pd.

Aroga, M. R. (2011). Corruption and Decentralised Public Governance. International Journal of Governance, Vol. 1 (3), pp.11-32.

Asante, S.K. (2013). The African peer review mechanism (APRM) as Africa's innovative thinking on governance: A decade of Ghana's experience. Accra: Digibooks Ghana Ltd.

Blay-Amihere, K. (2016). Political ownership of media houses cause of hate-speech (Address at a Public Forum on Media, Hate Speech and Peaceful Elections in Ghana). Retrieved from http://www.ghanaweb.com/GhanaHomePage/NewsArchive/Politicalownership-of-media-houses-cause-of-hate-speech-

Buckley, S., Apenteng, B., Bathily, A., \& Mtimde, L. (2005). Ghana Broadcasting study (World Bank's Report). Retrieved from http://siteresources.worldbank.org/INTCEERD/Resources/WBIGhanaBroadc sting.pdf.

Carpentier, N., Lie, R., \& Sevaes, J. (2008). Making community media work: Community media identities and their identities in an Antwerp neighbourhood development project. In Servaes (Ed.), Communication for Development and Social Change (pp. 347-373), California: SAGE Publications.

Coronel, S.S. (2005). Mass media on the attack in Southeast Asia. In James, B. (Ed.), Media and governance (pp. 28-30), Paris: UNESCO.

Diedong, A. \& Naaikuur, L. (2012). Ghana's experience in participatory community radio broadcasting. Global Media Journal, 6(2), 123-147.

GCRN (2014). Community radio non-partisanship Code". A code formulated from research on partisanship experiences by member stations to protect the nonpartisan status of community radio in Ghana.

GTV, Programme (November, 2020). GBC @ 85 panel discussion on Media and Democracy, Accra, Ghana.

Gumucio-Dagron, A. (2001). Making waves: Stories of participatory communication for social change. New York: Rockfeller Foundation

Grindle, G.S. (2007). Going Local: Decentralisation, democratisation, and the promise of good governance. New Jersey: Princeton University Press.

Haider M., Mcloughin, C. \& Scott, C. (2010). Topic guide on communication and governance. Retrieved from

http://siteresources.worldbank.org/EXTGOVACC/Resources/CommunicatioGo vernanceTGedition2.pdf

Hyden, G., Leslie, M., \& Ogundimu, F. (Eds) (2002). Media and democracy in Africa. New Jersey: Transaction Publishers. 
Jallov, B. (2012). Empowerment radio: Voices building community. Denmark: Hamilton Press.

Karikari, K. (2020). Broadcasting pluralism: Press freedom and democratic governance, 25 years after 'Radio Eye'. In K. Akpabli (Ed.), Plenty talk dey 4 Ghana (pp. 41-64). Accra: Anansem Publications.

Karikari, K. (2014). Paradox of voice without accountability in Ghana (Paper presented at the Kronti ne Akwamu Series, No. 10, organised by the CDDGhana). Retrieved from the CCD-Ghana, Accra.

Mansuri, G. \& Vijayendra, R. (2012). Localizing development: Does participation work? Washington, D.C. The World Bank.

McNeil, M. \& Mumvuma, T. (2006). Demanding good governance: A stocktaking of social accountability initiatives by civil society in Anglophone Africa. Washington D.C. World Bank.

MWFA (2014). Radio coverage of local governance in selected districts in Ghana (MFWA's policy brief). Retrieved from http://mfwa.africafex.org/wpcontent/uploads/2015/11/Radio-Coverage-of-Selected-Districts-in-Ghana.pdf.

MFWA (2015). Using radio to improve effective, participatory and accountable local governance in Ghana. (MFWA's Policy Brief on Social accountability platform for local governance performance in Ghana project). Retrieved from MFWA, Accra.

Mumin, A. Y. (2014). An assessment of the current level of citizens-local authorities' engagement on revenue inflow and expenditure in selected districts in Northern Ghana (MFWA's report). Retrieved from http://mfwa.africafex.org/wpcontent/uploads/2015/11/Citizen-Authorities Engagement-Platform-within-Ghanas-Local-Governance-System.pdf.

NCA) (2018). Authorised FM radio stations as at the third quarter of 2018. Retrieved from NCA's website: https://nca.org.gh/media-andnews/news/authorised-fm-radiostations-as-at-second-quarter-of-2018/

Naaikuur, L. (2020). Exploring the Contributions of Community Radio to Local Governance in Wenchi Municipality, Ghana. Dissertation submitted to the Aalborg University, Denmark.

Norris, P., \& Odugbemie, S. (2010). Evaluating media performance. In Norris, P. (Eds). Public sentinel: News media and governance reform (pp. 1-29). Washington, D.C: World Ban.

Nyamnjoh, M.B. (2005). Africa's media: Democracy and the politics of belonging. London: ZED BOOKS.

Ofei-Aboagye, O. D. (2008). The challenge of decentralisation. In Agyeman-Duah, D. (Ed.), Ghana Governance in the Fourth Republic (pp.234-262). Tema: Digibooks. Oluwu, D. \& Wunsch, S.J. (eds.) (2004). Local Governance in Africa: The Challenges of Democratic Decentralisation. London: Lynne Rienner Publishers. 
Oxhorn, P., Tulchin, S.J., \& Selee, D. (eds.) (2004). Decentralisation, democratic governance, and civil society in perspective: Africa and Latin America. Washington D.C.: Woodrow Wilson Centre Press.

Jallov, B. (2012). Empowerment radio: Voices building community. Denmark: Hamilton Press.

Santi, E. (2012). Decentralisation and governance in developing countries: The case of Ghana. Saarbrucken, Deutschland: Lambert Academic Publishing.

Servaes, J (2009). Communication policies, good governance and development journalism. Routledge \& Taylor's Francis Taylor's Group, 35 (1) pp 50-80. Unisa Press.

Shah, S.A. (Ed.) (2006). Local Governance in Developing Countries. Washington, D.C. The World Bank

Mansuri, G. \& Vijayendra, R. (2013). Localizing development: Does participation work? Washington, D.C. The World Bank.

Rodriguez, C. \& Miralles, M.A (2014). Citizens' journalism shifting public spheres from elites to citizens. In Wilkins, G.N, Tufte, T. \& Obregon, R. (Eds.), The Handbook of Development Communication and Social change (pp. 393-425), New Jersey: John Wiley \& Sons

UNDP (1997). Governance for sustainable human development. New York: UNDP.

Elahi, E.K. (2007). UNDP on good governance. International Journal of Social Economics, 36 (12) pp. 1167-1180.

White, R.A. (2008). The role of media and democratisation in Africa. African communication research, 1 (3), pp. 269-328.

White, R.A. (2009). Grassroots, participatory communication in Africa. Communication Research Trends, 28 (1), pp. 1-43.

Wildermuth, N. (2014). Communication for transparency and social accountability. In G.K Wilkens; M. Tufle \& R. Obregon (Eds), Handbook of development communication and social change (pp1-4). John Wiley \& Sons: New Jersey. World Bank (2005). Social accountability in the public sector: Conceptual discussion and learning model. Washington D.C.: World Bank. 